МЕХАНИЧЕСКАЯ ОБРАБОТКА ДРЕВЕСИНЫ

И ДРЕВЕСИНОВЕДЕНИЕ

УДК $630 * 6$

DOI: 10.37482/0536-1036-2021-6-150-159

\title{
INTERRELATIONS OF WOOD PHYSICAL AND MECHANICAL PROPERTIES AND PATTERNS OF THEIR CHANGE WITHIN THE BIRCH STEM
}

Vladimir I. Fedyukov, Doctor of Engineering, Prof.; ResearcherID: ABC-7222-2021, ORCID: https://orcid.org/0000-0003-4146-463X

Vasilii Yu. Chernov, Candidate of Engineering, Assoc. Prof.; ResearcherID: X-4439-2019, ORCID: https://orcid.org/0000-0001-9496-7340

Maria S. Chernova, Postgraduate Student; ResearcherID: X-4073-2019,

ORCID: https://orcid.org/0000-0002-0192-5158

Olga V. Tsoy, External PhD Student; ResearcherID: ABC-7278-2021,

ORCID: https://orcid.org/0000-0001-8028-2201

Volga State University of Technology, pl. Lenina, 3, Yoshkar-Ola, Mari El Republic, 424000, Russian Federation; e-mail: fiv48@mail.ru, chernovvy@volgatech.net

Original article / Received on October 21, 2020 / Accepted on December 25, 2020

Abstract. The physical and mechanical properties of standing wood are not constant along the tree height and diameter. They also differ depending on the tree species and conditions of its growth. So, the research purpose is to identify patterns of change and interrelations between the parameters of density, compressive strength and sound propagation velocity along the wood fibers inside the stem of a birch tree growing in the forests of the Middle Volga region of Russia, where such research had never been conducted before. The work was carried out on two sampling areas laid out by standard methods in birch forests of natural origin with average productive capacity on the territory of the Scientific-Experimental Forest District of the Volga State University of Technology in the Mari El Republic. The average age of the birch trees is about 70 yrs, breast height diameter is $30 \mathrm{~cm}$, and height is $28.5 \mathrm{~m}$; 14 sample trees were studied; $0.5 \mathrm{~m}$ long chucks were cut out from their stems at a height of $1.3 \mathrm{~m}$ from the butt end and at relative heights of $0.25 \mathrm{H}, 0.5 \mathrm{H}$, and $0.75 \mathrm{H}$. Experimental work was carried out in a laboratory environment with modern technical facilities using standard procedures. Mathematical models describing the changes in the parameters stated above and the interrelations between them with regard to the stem diameter at relative heights were obtained. The research results generally confirmed the findings of other researchers on densitograms and other physical and mechanical properties of wood within the tree stem. However, the features listed above were revealed for birch trees growing under such conditions; in particular, it concerns the ratio of strength and density, as well as the wood strength and the velocity of sound propagation through the fibers. The results obtained have both scientific and practical value as a basis for the development of a non-destructive method for predicting technical properties of standing wood as well as timber for producing assortments for special purposes.

For citation: Fedyukov V.I., Chernov V.Yu., Chernova M.S., Tsoy O.V. Interrelations of Wood Physical and Mechanical Properties and Patterns of Their Change within the Birch Stem. Lesnoy Zhurnal [Russian Forestry Journal], 2021, no. 6, pp. 150-159. DOI: 10.37482/05361036-2021-6-150-159

This is an open access article distributed under the terms of the Creative Commons Attribution 4.0 International (CC BY 4.0) license • The authors declare that there is no conflict of interest 
Funding: The research was supported by the Ministry of Science and Higher Education of the Russian Federation (Grant No. 075-15-2021-674) and the Core Facility Centre "Ecology, Biotechnology, and Processes for Producing Environmentally Friendly Energy Carriers" of the Volga State University of Technology, Yoshkar-Ola.

Keywords: birch wood, wood density, compressive strength along the grain, sound velocity, interrelation of physical and mechanical parameters.

\section{ВЗАИМОСВЯЗИ ФИЗИКО-МЕХАНИЧЕСКИХ СВОЙСТВ ДРЕВЕСИНЫ И ЗАКОНОМЕРНОСТИ ИХ ИЗМЕНЕНИЯ ВНУТРИ СТВОЛА БЕРЕЗЫ}

В.И. Федюков, д-р техн. наук, проф.; ResearcherID: ABC-7222-2021,

ORCID: https://orcid.org/0000-0003-4146-463X

В.Ю. Чернов, канд. техн. наук, дои..; ResearcherID: X-4439-2019,

ORCID: https://orcid.org/0000-0001-9496-7340

M.С. Чернова, аспирант; ResearcherID: X-4073-2019,

ORCID: https://orcid.org/0000-0002-0192-5158

O.В. Цой, соискатель; ResearcherID: ABC-7278-2021,

ORCID: https://orcid.org/0000-0001-8028-2201

Поволжский государственный технологический университет, пл. Ленина, д. 3, г. Йошкар-Ола, Республика Марий Эл, Россия, 424000; e-mail: fiv48@mail.ru

Оригинальная статья / Поступила в редакцию 21.10.20 / Принята к печати 25.12.20

Аннотация. Физико-механические свойства древесины у растущих деревьев варьируют по высоте и диаметру дерева, а также различаются в зависимости от породы дерева и условий его произрастания. Целью исследования было выявление закономерностей изменения плотности, прочности на сжатие и скорости распространения звука вдоль волокон древесины и взаимосвязей между этими признаками внутри ствола березы, произрастающей в лесах Среднего Поволжья России, где подобные исследования раньше не проводились. Работа выполнена на двух пробных площадях, заложенных стандартными методами в березовых лесах естественного происхождения со средней продуктивностью на территории учебно-опытного лесхоза Поволжского государственного технологического университета в Республике Марий Эл. Средний возраст берез - около 70 лет, диаметр - 30 см, высота - 28,5 м. Отобрано 14 модельных деревьев. Из их стволов на высоте 1,3 м от торца и на относительных высотах $0,25 \mathrm{H} ; 0,5 \mathrm{H} ; 0,75 \mathrm{H}$ вырезаны чураки длиной по 0,5 м. Экспериментальные работы проведены в лабораторных условиях с помощью современных технических средств при использовании стандартных процедур. Получены математические модели, характеризующие изменения изучаемых параметров и взаимосвязи между ними с учетом диаметра ствола на относительных высотах. Результаты подтвердили выводы исследователей о характере денситограмм и других физико-механических свойствах древесины внутри ствола дерева. Однако для березы, произрастающей в описанных выше условиях, выявлены особенности соотношения прочности и плотности, а также прочности древесины и скорости распространения звука по волокнам. Полученные данные имеют научную и практическую ценность как основа для разработки неразрушающего метода прогнозирования технических свойств древесины на корню, а также древесины для получения сортиментов специального назначения.

Данная статья опубликована в режиме открытого доступа и распространяется на условиях лицензии Creative Commons «Attribution» («Атрибуция») 4.0 Всемирная (СС ВY 4.0) • Авторы заявляют об отсутствии конфликта интересов 
Для цитирования: Fedyukov V.I., Chernov V.Yu., Chernova M.S., Tsoy O.V. Interrelations of Wood Physical and Mechanical Properties and Patterns of Their Change within the Birch Stem // Изв. вузов. Лесн. журн. 2021. № 6. C. 150-159. DOI: 10.37482/0536-1036-20216-150-159

Финансирование: Работа выполнена при поддержке Министерства науки и высшего образования Российской Федерации (грант № 075-15-2021-674) и ЦКП «Экология, биотехнологии и процессы получения экологически чистых энергоносителей» Поволжского государственного технологического университета в г. Йошкар-Ола.

Ключевые слова: древесина березы, плотность древесины, прочность на сжатие вдоль волокон, скорость звука, взаимосвязь физико-механических показателей.

\section{Introduction}

Physical and mechanical properties of wood are known to vary greatly not only depending on the species but also within the stem diameter and height of the same tree. In woodworking technology for achieving the maximum yield of highquality products made of a volume unit of raw materials its proper rough cutting plays an important role; with regard to the technical properties of wood in different parts of the stem. As for the birch timber, this applies first to the manufacture of special types of products, such as stocks for certain types of weapons, hunting skis, sports equipment, individual parts of musical instruments, frame structures, special veneer for interior covering of aircraft and submarines, etc. Special purpose timber with certain requirements to density, durability, and acoustics is harvested in order to produce all mentioned above.

The birch is the most common deciduous species in Russian forests. In the State Forest Fund the share of birch forests in terms of the timber stock is approximately $78 \%$ among small-leaved deciduous species. Moreover, two species, namely, silver birch (Betula pendula Roth) and downly birch (Betula pubescens Ehrh) dominate by area and standing timber [4].

Despite the remarkable predominance of birch, so far the greatest number of studies with respect to forest site conditions of Russia are devoted to the study of other wood species: spruce and pine $[5,10,11]$, to a lesser extent aspen, oak and maple $[6,15,21,22]$, and only a few works devoted to birch are found $[3,4,12,13]$. Recently there have appeared academic papers devoted to changes in the properties of birch wood due to its modification $[11,20]$.

It is important to emphasize that in current conditions, foreign scientists and specialists began to actively study the wood of this species in different regions of the world. Along with traditional physical tests, they carry out more in-depth scientific studies of its properties, such as non-destructive methods and computer tomography.

\section{Research objects and methods}

Birch stands of natural (seed) origin were employed as an object of the research on the territory of the Scientific-Experimental Forest District of the Volga State University of Technology (VSUT). Sample plots are represented by birch and linden stands of the 11th quality class typical for the Middle Volga region. The stand 
inventory indices are as follows: the average age of birch trees is $70 \mathrm{yrs}$; their breast height diameter $(\mathrm{DBH})$ is approximately $30 \mathrm{~cm}$; and the height is $28.5 \mathrm{~m}$.

Two sampling areas were laid out in these stands according to the state standard GOST 16483.0-80 "Wood. General Requirements for Physical and Mechanical Tests".

Before felling, the DBH of each model tree was measured in two mutually perpendicular directions within the accuracy of $0.5 \mathrm{~cm}$ and a notch was made on the north side of each tree.

Then the total length, the distance from the butt end to the first visible dead knot and to the live crown, as well as the stem diameter at relative heights of $0.25 \mathrm{H}$, $0.5 \mathrm{H}$, and $0.75 \mathrm{H}$ were measured for each felled model tree. At each of these heights and at $1.3 \mathrm{~m}$ height $0.5 \mathrm{~m}$ long chucks were cut out from the tree length stem (fig.).

Sampling scheme

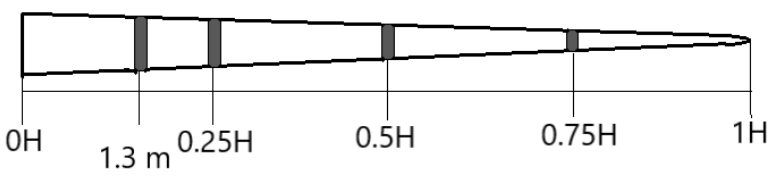

The chucks were divided in half into so-called "north" and "south" parts. Standard samples from each of them were made in the form of $20 \times 20 \times 30 \mathrm{~mm}$ rectangular strips at a distance of $0.25 \mathrm{R}, 0.5 \mathrm{R}$ and $0.75 \mathrm{R}$ from the pith. These samples were originally used for acoustic tests, and after they were carried out, $20 \times 20 \times 30 \mathrm{~mm}$ rectangular prisms were cut out at both ends of the strips for determining wood density and compressive strength.

The test samples were kept for 60 days prior to testing in the laboratory for drying under natural conditions to room-dry humidity ( $W=8 \pm 2 \%$ ).

Determination of wood density. During the study of the physical properties of the birch wood its basic density $\left(\rho_{\text {bas }}, \mathrm{kg} / \mathrm{m}^{3}\right)$ was determined by the ratio of its ovendry sample weight $\left(m_{0}, \mathrm{~kg}\right)$ to its maximum volume $\left(V_{\max }, \mathrm{m}^{3}\right)$ at humidity equal to or above the fiber saturation point according to the following equation:

$$
\rho_{\text {bas }}=m_{0} / V_{\text {max }} \text {. }
$$

The sample basic density was determined by the method of the buoyancy force of the sample immersed in a fluid [17].

The average density of the stem cross section $\left(\rho_{\mathrm{cs}}\right)$ was determined by the method of prof. O.I. Poluboyarinov [17] as a weighted average between the densities $\rho_{0.25 R}, \rho_{0.5 \mathrm{R}}$, and $\rho_{0.75 \mathrm{R}}$.

Assuming the basal area to be $100 \%$, the average cross section density will be calculated by the following equation:

$$
\rho_{\mathrm{cs}}=\frac{\rho_{0.25 \mathrm{R}} \cdot 7+\rho_{0.5 \mathrm{R}} \cdot 29+\rho_{0.75 \mathrm{R}} \cdot 64}{100},
$$

where $\rho_{0.25 R}, \rho_{0.5 \mathrm{R}}$, and $\rho_{0.75 \mathrm{R}}-$ wood densities at $0.25 \mathrm{R}, 0.5 \mathrm{R}$, and $0.75 \mathrm{R}$ distance from the stem center, respectively, $\mathrm{kg} / \mathrm{m}^{3} ; 7,29$, and 64 -area occupied by wood ring sections, $\%$.

Average stem basic density was determined as the weighted average of the densities of the individual parts (chucks) along its height by the following equation: 


$$
\rho_{\text {tree }}=\frac{\rho_{1.3 \mathrm{~m}} V_{1.3 \mathrm{~m}}+\rho_{0.25 \mathrm{H}} V_{0.25 \mathrm{H}}+\rho_{0.5 \mathrm{H}} V_{0.5 \mathrm{H}}+\rho_{0.75 \mathrm{H}} V_{0.75 \mathrm{H}}}{V_{1.3 \mathrm{~m}}+V_{0.25 \mathrm{H}}+V_{0.5 \mathrm{H}}+V_{0.75 \mathrm{H}}},
$$

where $\rho_{1.3 \mathrm{~m}}, \rho_{0.25 \mathrm{H}}, \rho_{0.5 \mathrm{H}}$, and $\rho_{0.75 \mathrm{H}}-$ stem (chuck) cross section densities at heights of $1.3 \mathrm{~m}, 0.25 \mathrm{H}, 0.5 \mathrm{H}$, and $0.75 \mathrm{H}$, respectively, $\mathrm{kg} / \mathrm{m}^{3} ; V_{1.3 \mathrm{~m}}, V_{0.25 \mathrm{H}}, V_{0.5 \mathrm{H}}$, and $V_{0.75 \mathrm{H}}-$ volumes of individual sections along the tree height at heights of $1.3 \mathrm{~m}, 0.25 \mathrm{H}, 0.5 \mathrm{H}$, and $0.75 \mathrm{H}$, respectively, $\mathrm{m}^{3}$.

Determination of wood compressive strength along the grain. The studies were carried out in accordance with the state standard GOST 16483.10 "Wood. Methods for Determination of Ultimate Strength in Compression Parallel the Grain". The same samples were taken for this purpose, using which the basic density of wood was determined earlier.

Wood compressive strength along the grain $\left(\sigma_{w}, \mathrm{MPa}\right)$ was determined according to the standard equation:

$$
\sigma_{w}=P_{\max } / a b,
$$

where $P_{\max }$ - maximum load, $\mathrm{N} ; a$ and $b$-dimensions of a sample cross section, $\mathrm{mm}$.

Determination of the wood compressive strength was carried out with the universal testing machine AG-50 kNIC allowing receiving simultaneously real-time readings of the maximum load $P_{\max }$, graphic image of the wood destruction process and the final values of $\sigma_{w}$.

Determination of the sound velocity in wood. Acoustic properties of the birch wood along with its strength are considered in manufacturing the mechanical parts of musical instruments, antiresonance veneer for covering internal walls of submarines and in soundproof structures of individual buildings. The material used for this purpose should have a lower sound velocity.

The simplest and most available method for determining sound velocity $(C)$ in wood is the ultrasonic pulse velocity (UPV) method, and the calculations are carried out according to the following equation:

$$
C=l / \tau,
$$

where $l$ - length of a sample, $\mathrm{m} ; \tau$ - time of longitudinal elastic wave propagation, $\mathrm{s}$.

Determination of the sound propagation velocity along the fibers was carried out on the standard samples in the form of rectangular strips of $20 \times 20 \times 300 \mathrm{~mm}$ using the ultrasonic pulse detector UK-14P. In order to achieve better contact of the device with the test sample a rubber sheet (adhesive tape) was glued to the surface of piezoelectric detectors, and measurements were carried out at a frequency of $60 \mathrm{kHz}$.

It is important to mention that ultrasonic devices have found wide application in the selection of resonant coniferous timber [5]. Until now no research has been done on the development of non-destructive acoustic diagnostic methods of physical and mechanical properties of deciduous wood, especially of standing birch. This work is aimed to some extent at solving this important practical issue.

\section{Results and discussion}

Wood density. The wood density distribution by height and radius zones is shown in table 1, while table 2 shows the results of statistical processing of the obtained data. 
Table 1

Changing the basic density of birch wood by height and stem radius

\begin{tabular}{|c|c|c|c|c|}
\hline \multirow{2}{*}{$\begin{array}{c}\text { Section height in } \\
\text { shares of the stem } \\
\text { height }\end{array}$} & \multicolumn{3}{|c|}{ Basic density by the stem cross sections, $\mathrm{kg} / \mathrm{m}^{3}$} & \multirow{2}{*}{$\begin{array}{c}\text { Average density of } \\
\text { the stem cross section, } \\
\mathrm{kg} / \mathrm{m}^{3}\end{array}$} \\
\hline & $0.25 \mathrm{R}$ & $0.5 \mathrm{R}$ & $0.75 \mathrm{R}$ & \\
\hline $1.3 \mathrm{~m}$ & 483 & 509 & 543 & 512 \\
\hline $0.25 \mathrm{H}$ & 479 & 502 & 521 & 501 \\
\hline $0.5 \mathrm{H}$ & 474 & 508 & 517 & 495 \\
\hline $0.75 \mathrm{H}$ & 461 & 484 & 507 & 482 \\
\hline
\end{tabular}

Note: The average density of the stem section is obtained as the average of cross section zones.

Table 2

The main statistical indicators of the average basic density by the birch stem sections

\begin{tabular}{|c|c|c|c|c|c|}
\hline $\begin{array}{c}\text { Section height in } \\
\text { shares of the stem } \\
\text { height }\end{array}$ & \multicolumn{5}{|c|}{ Values of statistical indicators } \\
\cline { 2 - 6 } & $\bar{M}$ & $\pm \sigma$ & $\mathrm{V}, \%$ & $\pm \mathrm{m}$ & $\mathrm{P}, \%$ \\
\hline $1.3 \mathrm{~m}$ & 512 & 39.74 & 7.76 & 8.67 & 1.69 \\
\hline $0.25 \mathrm{H}$ & 501 & 32.23 & 6.44 & 7.03 & 1.40 \\
\hline $0.5 \mathrm{H}$ & 495 & 28.15 & 5.69 & 6.63 & 1.34 \\
\hline $0.75 \mathrm{H}$ & 482 & 28.11 & 5.83 & 6.45 & 1.34 \\
\hline
\end{tabular}

As can be seen from tables 1 and 2, a decrease in the birch wood density by tree height is proved statistically; similar character variability of this physical parameter is consistent with previous results obtained in other regions [3, 12, 17]. In this regard a recent work of foreign scientists [7] is of particular interest. It shows lower height dependence of birch wood density compared to spruce and pine, which is associated with peculiar tree crown structure of different species. The birch is a light demanding species, so it has a relatively rapid clearing of stem from limbs, and, as a consequence, a stem with a highly raised crown is formed. The annual rings formed in the tree butt are known for the high content of late wood; as a result, the wood density here is relatively high.

Deeper anatomical studies [16] confirm the reduction in wood density along the birch stem by the increase of vascular area and the content of parenchyma in the cells of the tree top end.

In the horizontal plane the wood density increases from the center to the peripheral zone. A detailed analysis shown in table 3 proves that density reduction in the direction from the peripheral zone to the heartwood is approximately $9.5 \%$, and from the stem butt to the top it is $5.9 \%$. Technically, e.g. when cutting tree length stems to assortments, the density change by height in the range of $6 \%$ is not significant. The density dynamics in the horizontal planes of the stem cross section has greater practical importance, because it determines a significant difference in the specific yield of high-quality assortments, as well as dry matter from the stem heartwood and peripheral zones.

The studies confirmed close relationship between wood density $\rho_{\text {tree }}$ and average density of the cross section at height of $1.3 \mathrm{~m}\left(\rho_{1.3 \mathrm{~m}}\right)$ by the following equation:

$$
\rho_{\text {tree }}=178.52+0.641 \rho_{1.3 \mathrm{~m}}, r=0.922,
$$

where $r$-correlation coefficient. 
For the birch wood, the relationship is also found between the average density of a tree and the density of the peripheral zone of the stem $\rho_{0.75 \mathrm{R}}$ at height of $1.3 \mathrm{~m}$ by the following equation:

$$
\rho_{\mathrm{cs}}=67.3+0.853 \rho_{0.75 \mathrm{R}}, \quad r=0.982 .
$$

Using equation (1), it is possible to calculate the density of the entire birch stem based on the wood density parameter at the height of $1.3 \mathrm{~m}$ of the felled tree. However, equation (2) is of greater practical importance, since it makes possible to determine the physical parameter mentioned above even without felling the tree. It is sufficient to extract a transverse-radial core from the peripheral part of the stem of about $0.75 \mathrm{R}$ at the height of $1.3 \mathrm{~m}$ with a hollow drill and determine the basic density of this sample.

Wood compressive strength along the grain. Table 3 shows the resulting values of the compressive strength along the grain by radius zones (heartwood, center, peripheral) and the stem height $(1.3 \mathrm{~m}, 0.25 \mathrm{H}, 0.5 \mathrm{H}$, and $0.75 \mathrm{H})$. Such a division is justified by the set aim of identifying the best stem zone for obtaining special purpose assortments with high physical and mechanical properties of wood.

Table 3

Changing the compressive strength $\left(\sigma_{w}, \mathrm{MPa}\right)$ along the grain of birch wood by stem height and radius zones

\begin{tabular}{|l|c|c|c|c|}
\hline \multirow{2}{*}{\begin{tabular}{c}
\multirow{2}{*}{$\begin{array}{c}\text { Section } \\
\text { in the stem }\end{array}$} \\
\cline { 2 - 4 }
\end{tabular}} & $\overline{\mathrm{M}}$ & $\pm \sigma$ & $\mathrm{V}, \%$ & $\pm \mathrm{m}$ \\
\hline $1.3 \mathrm{~m}$ & 63.6 & 9.5 & 14.9 & 2.1 \\
\hline $0.25 \mathrm{H}$ & 66.0 & 7.0 & 10.6 & 1.6 \\
\hline $0.5 \mathrm{H}$ & 64.5 & 9.3 & 14.4 & 2.2 \\
\hline $0.75 \mathrm{H}$ & 61.3 & 8.3 & 13.5 & 1.9 \\
\hline \multicolumn{5}{|c|}{ By the radius zones } \\
\hline Heartwood & 56.9 & 7.0 & 12.3 & 1.3 \\
\hline Center & 64.5 & 5.6 & 8.7 & 1.1 \\
\hline Peripheral & 71.1 & 6.9 & 9.7 & 1.4 \\
\hline
\end{tabular}

Note: Heartwood, center and peripheral zones correspond to the $0.25 \mathrm{R}, 0.5 \mathrm{R}$, and $0.75 \mathrm{R}$ stem sizes.

The test results for the compressive strength along the grain show an increase in strength of birch wood in the transverse direction from the core to the cambium layer and a decrease in longitudinal direction from the butt to the top of the stem. An exception is the value of tensile strength in the cross section at the height of $1.3 \mathrm{~m}$. This is due to the deviation from the straight direction of the fibers, arising from the strong pressure on the wood of the stem lower part of the above-mentioned zones of the growing tree.

It is known that there is a close interrelation between density, strength and hardness of wood $[19,23]$. The results obtained show that the interrelation of the birch wood strength in compression along the grain and the density under given forest site conditions is expressed by the following equation:

$$
\sigma_{w}=0.211 \rho_{\text {bas }}-44.44, r=0.83 \text {, }
$$

where $\sigma_{w}$ - birch wood compressive strength along the grain in room conditions $(W=8 \%), \mathrm{MPa}$. 
Using equation (3), it is possible to predict strength properties of the birch wood according to its basic density without additional mechanical testing. This greatly simplifies and reduces costs when sorting special purpose workpieces with specified material strength requirements.

Sound velocity in wood. Average values of sound velocity along the stem height and radius zones are given in table 4 .

Table 4 shows that the sound velocity varies by the stem zones similar to the change of the wood compressive strength along the grain: it increases from the center to the periphery zone of the stem and decreases from the stem butt up the stem. An exception is the height of $1.3 \mathrm{~m}$ as well as for the compressive strength along the grain. This can also be explained by a change in the straight direction of the fibers in the stem butt.

An equation for the interrelation between wood strength and sound velocity along the fibers has been obtained by correlation analysis:

$$
\sigma=0.0345 C-125.64, r=0.792,
$$

where $\sigma$ - compressive strength along the grain, $\mathrm{MPa}$.

Table 4

Changing the sound velocity $(C, \mathrm{~m} / \mathrm{s})$ along the fibers of birch wood by height and radius zones

\begin{tabular}{|l|c|c|c|c|}
\hline \multirow{2}{*}{$\begin{array}{c}\text { Section } \\
\text { of the stem }\end{array}$} & $\overline{4}$ Values of statistical indicators \\
\cline { 2 - 5 } & $\overline{\mathrm{M}}$ & $\pm \sigma$ & $\mathrm{V}, \%$ & $\pm \mathrm{m}$ \\
\hline $1.3 \mathrm{~m}$ & 5453 & 167 & 3.1 & 36 \\
\hline $0.25 \mathrm{H}$ & 5576 & 197 & 3.5 & 43 \\
\hline $0.5 \mathrm{H}$ & 5535 & 189 & 3.4 & 45 \\
\hline $0.75 \mathrm{H}$ & 5388 & 188 & 3.5 & 42 \\
\hline \multicolumn{5}{|c|}{ By the radius zones } \\
\hline Heartwood & 5304 & 136 & 2.6 & 26 \\
\hline Center & 5538 & 145 & 2.6 & 27 \\
\hline Peripheral & 5643 & 129 & 2.3 & 26 \\
\hline
\end{tabular}

Scientifically, this interrelation of sound velocity along the fibers and compressive strength in the same direction can be explained by the features of wood structure inside the tree stem. For example, the content of late wood in annual layers decreases from the butt to the top of the tree, and in transverse direction - from the periphery to the heartwood. This has a direct impact on the distribution of density, strength and, consequently, the sound propagation velocity.

It is obvious that such substantiation describes only a general picture of the interrelations between these parameters. Wood is a material of biological origin with a complex structure, e.g. it differs by content of juvenile wood, internal flaws, fibril tilt, etc. Together, they bring their own adjustments to the interrelations of the physical and mechanical parameters of wood, which cannot be identified by traditional physical testing methods.

Although the model trees were without a false core, they definitely had juvenile wood; in the butt part, in addition, trees sometimes have natural fiber deviation from straight direction. Perhaps, together, all these affected the reduction of strength and sound propagation velocity in the wood at the stem height of $1.3 \mathrm{~m}$ (tables 3 and 4). 
Equation (4) allows implementing the non-destructive quality control method of birch stock dimension with an ultrasonic flaw detector. The compressive strength along the grain is calculated via determining the sound velocity and using this equation. Comparing the obtained results with standard indicators, it is not complicated to make a non-destructive selection of assortments for the intended purpose.

Besides, ultrasonic devices can detect hidden, invisible on the outer surface of the examined material wood defects: internal knots, cracks and other flaws according to the state standard GOST 2140-81 "Visible Defects of Wood. Classification, Terms and Definitions, Methods of Measurement".

\section{Conclusion}

There are certain patterns in the dynamics of wood physical and mechanical properties within the birch stem. In general, these patterns correlate with the results of other scientists from different regions: wood density decreases with tree height; in the horizontal plane it increases from the center to the peripheral zone; whereas the decrease in density from the peripheral zone of the stem to the core zone is about $9.5 \%$, and from the butt to the top is $5.9 \%$.

However, there are specific features in the densitogram and in the interrelation of density, compressive strength and sound velocity along the fibers in these forest site conditions.

The resulting equations of constraints between them make it possible to introduce the non-destructive method for diagnosis of physical and mechanical properties of standing wood. For this purpose, it is only necessary to use a hollow drill to extract a transverse-radial core from the peripheral part of the stem of about $0.75 \mathrm{R}$ at the height of $1.3 \mathrm{~m}$ and determine one of the parameters of this sample, and subsequently by calculation to determine its value at other relative tree heights $0.25 \mathrm{H} ; 0.5 \mathrm{H} ; 0.75 \mathrm{H}$.

The same equations of constraints between physical and mechanical properties make it possible to speed up and minimize the cost for wood testing without its felling. For example, by determining the basic density at the height of $1.3 \mathrm{~m}$ it is possible to predict the strength parameter of the whole stem by calculation.

The conclusions are substantiated by the results of physical methods of wood testing. The authors plan to carry out more in-depth scientific research using both traditional and modern methods, e.g. computed tomography with subsequent comparative analysis of the results.

\section{REFERENCES}

1. Bello A.A., Jimoh A.A. Some Physical and Mechanical Properties of African Birch (Anogeissus leiocarpus) Timber. Journal of Applied Sciences and Environmental Management, 2018, vol. 22, iss. 1, pp. 79-84. DOI: https://doi.org/10.4314/jasem.v22i1.14

2. Collins S., Fink G. Mechanical Behaviour of Sawn Timber of Silver Birch under Compression Loading. Wood Material Science \& Engineering, 2020, pp. 1-8. DOI: https:// doi.org/10.1080/17480272.2020.1801836

3. Danilov D.A. Features of Mixed Stands Formation, Commodity Structure and Wood Density of Pine and Spruce Trees: Dr. Agric. Sci. Diss. Abs. Saint Petersburg, 2016. 41 p.

4. Denisov S.A. Birch Forests of the Middle Volga Region: Biology, Ecology and Integrated Economy in Birch Forests of Betula pendula Roth and Betula pubescens Ehrh: Dr. Agric. Sci. Diss. Abs. Yoshkar-Ola, 1999. 40 p. 
5. Fedyukov V.I. Resonant Spruce: Selection from Stands, Cultivation, and Intended Use: Monograph. Yoshkar-Ola, VSUT Publ., 2016. 256 p.

6. Fedyukov V.I., Saldaeva E.Y., Chernova M.S., Chernov V.Y. Research into DendroAcoustic Properties of Introduced Clones' Wood as Material for Manufacturing Musical Instruments. SEEFOR, 2019, vol. 10, no. 2, pp. 173-179. DOI: https://doi.org/10.15177/seefor.19-18

7. Heräjärvi H. Variation of Basic Density and Brinell Hardness within Mature Finnish Betula pendula and B. pubescens Stems. Wood and Fiber Science, 2004, vol. 36, no. 2, pp. 216-227.

8. Liepinšs K., Rieksts-Riekstiňš J. Stemwood Density of Juvenile Silver Birch trees (Betula pendula Roth.) from Plantations on Former Farmlands. Baltic Forestry, 2013, vol. 19(2), pp. 179-186.

9. Luostarinen K., Verkasalo E. Birch as Sawn Timber in Mechanical Further Processing in Finland. A Literature Study. Silva Fennica Monographs 1, 2000. 40 p.

10. Melekhov I.S. Significance of Forest Types and Forest Site Conditions in the Study of Wood Structure and Its Physical and Mechanical Properties. Trudy Instituta lesa AN SSSR, 1949, vol. 1U, pp. 11-21.

11. Melekhov V.I., Babich N.A., Korchagov S.A. Qualitative Characteristics of Pine Wood on Plantations. Arkhangelsk, ASTU Publ., 2005. 116 p.

12. Mikheyevskaya M.A. Production of Pressed Wood with Homogeneous Quality Indicators: Cand. Eng. Sci. Diss. Voronezh, 2019. 250 p.

13. Musikhina L.A. Research and Development of Scientific and Methodological Bases of Qualimetry of Wood Raw Materials of the Volga-Vyatka Region: Cand. Eng. Sci. Diss. Yoshkar-Ola, 2005. 235 p.

14. Pavlovičs G., Dolacis J., Daugaviete M., Hrols J., Alksne A., Cīrule D. Comparison of the Physical and Mechanical Properties of the Wood of Wild Cherry (Prunus avium L.) and Birch (Betula pendula Roth.) Grown in Latvia. Annals of Warsaw University of Life Sciences - SGGW, Forestry and Wood Technology, 2006, vol. 59, pp. 164-168.

15. Pchelin V.I. Biological Bases of Cultivation of High-Quality Wood for Target Purpose: Case Study of Spruce and Aspen Forests of the Middle Volga Region: Dr. Agric. Sci. Diss. Yoshkar-Ola, 1989. 478 p.

16. Platonov A.D., Mikheevskaya M.A., Snegireva S.V., Kuryanova T.K., Kiseleva A.V., Topcheev A.N. The Influence of Vessels Variability on Wood Quality of Birch and Aspen in the Trunk of the Tree. Lesotekhnicheskiy zhurnal [Forestry Engineering Journal], 2018, vol. 8, no. 2(30). pp. 212-221. DOI: https://doi.org/10.12737/article 5b24061a94a5f2.93144911

17. Poluboyarinov O.I. Wood Density. Moscow, Lesnaya promyshlennost’ Publ., 1976. $159 \mathrm{p}$.

18. Pushinskis V., Mionchinskis U., Tuherm H., Hrols J., Dolacis J. Some Physical and Mechanical Properties of Birch (Betula pendula Roth.) Wood Growing in Latvia. Annals of Warsaw University of Life Sciences - SGGW, Forestry and Wood Technology, 2003, vol. 53, pp. 308-317.

19. Repola J. Models for Vertical Wood Density of Scots Pine, Norway Spruce and Birch Stems, and Their Application to Determine Average Wood Density. Silva Fennica, 2006, vol. 40, no. 4, pp. 673-685. DOI: https://doi.org/10.14214/sf.322

20. Sheykman D.V., Kosheleva D.V. Study of Physical and Mechanical Properties of Modified Birch and Aspen Wood. Vestnik tekhnologicheskogo universiteta [Bulletin of the Technological University], 2016, vol. 19, no. 15, pp. 110-112.

21. Shirnin V.K. Breeding for Wood Quality: Case Study of Common Oak and Other Species in the Central Chernozem Region: Dr. Agric. Sci. Diss. Voronezh, 1999. 302 p.

22. Vikhrov V.E. Oak Wood Structure and Properties. Moscow, AN SSSR Publ., 1954. $263 \mathrm{p}$.

23. Volynskiy V.N. On the Correlation of Timber Strength and a Number of Its Parameters. Lesnoy Zhurnal [Russian Forestry Journal], 1991, no. 1, pp. 60-64. URL: http:// lesnoizhurnal.ru/upload/iblock/706/60 64.pdf

Вклад авторов: Все авторы в равной доле участвовали в написании статьи Authors' Contribution: All authors contributed equally to the writing of the article 